\title{
Comparison of performance on a heat tolerance test of military personnel that have suffered heat illness and subsequently been diagnosed with malignant hyperthermia and controls
}

\author{
Carol House*, Dan Roiz de Sa \\ From 15th International Conference on Environmental Ergonomics (ICEE XV) \\ Portsmouth, UK. 28 June - 3 July 2015
}

\section{Introduction}

The Institute of Naval Medicine runs a Heat Illness Clinic (HIC), seeing about 140 military patients a year who have been referred following an episode of heat illness (HI). Patients undertake assessment of maximal aerobic fitness $\left(\mathrm{VO}_{2} \max \right)$ followed by a heat tolerance test (HTT), in which they walk on a treadmill at $60 \%$ $\mathrm{VO}_{2} \mathrm{max}$ in a warm environment $\left(34{ }^{\circ} \mathrm{C}\right.$ dry bulb, relative humidity $40 \%$ with a WBGT of $27{ }^{\circ} \mathrm{C}$ ). Initially patients are fully clothed and carry a rucksack (mass $14 \mathrm{~kg}$ ) to raise the deep body temperature, at $30 \mathrm{~min}$ the jacket and rucksack are removed and at $45 \mathrm{~min}$ the t-shirt removed. Patients continue to exercise until thermal equilibrium (i.e. a plateau of rectal temperature) is achieved (60 min to $90 \mathrm{~min})$. Rectal temperature $\left(\mathrm{T}_{\mathrm{re}}\right)$, mean skin temperature $\left(\mathrm{T}_{\mathrm{msk}}\right)$, heart rate $(\mathrm{HR})$ and sweat rate (SR) are recorded. Patients in which thermal equilibrium is not achieved are considered to demonstrate abnormal thermoregulation and "fail" the HTT. These patients are reviewed at least once a minimum of 8 weeks later, and if they consistently fail the HTT and there is a suspicion of malignant hyperthermia (MH) they are recommended for referral to the Malignant Hyperthermia Unit, Leeds. MH is a genetic condition in which too much calcium is released from the intracellular store into the cytoplasm in response to certain triggering agents, e.g. the anaesthetic halothane. This leads to a rise in cellular metabolism and heat production, particularly within skeletal muscle, and it has been

\footnotetext{
* Correspondence: carol.house721@mod.uk

Environmental Medicine and Science, Institute of Naval Medicine, Gosport,
} UK publicdomain/zero/1.0/) applies to the data made available in this article, unless otherwise stated.
The results suggest that individuals with $\mathrm{MH}$ will demonstrate heat intolerance when assessed in the INM $\mathrm{HIC}$, and this may make them more susceptible to HI. However, further work is required to determine the sensitivity and specificity of the HTT to detect MH. suggested that individuals with underlying $\mathrm{MH}$ are more

\section{Methods} had attended the HIC and were subsequently diagnosed with $\mathrm{MH}(\mathrm{n}=11)$, and data from military personnel with no history of HI who volunteered to undertake HIC assessments (controls, $\mathrm{n}=19$ ) were compared. Data were compared by one-way analysis of variance with pair-wise comparisons and Bonferroni correction using SPSS

\section{Results} and 45 to $60 \mathrm{~min}$ than the HIC patients that passed the HTT and the control group, and a lower absolute $\mathrm{O}_{2}$ max and higher $\mathrm{T}_{\mathrm{msk}}$ at 30,45 and 60 min than ferences in age, height, body mass, $\mathrm{VO}_{2}$ max relative to body mass or SR (absolute or compared to body surface area) between the MH group and the other two groups.

\section{Discussion}




\section{Conclusion}

Individuals with $\mathrm{MH}$ may demonstrate heat intolerance, which can be identified using the INM HTT.

Published: 14 September 2015

\section{Reference}

1. Hopkins PM: Is there a link between malignant hyperthermia and exertional heat illness? British Journal of Sports Medicine 2007, 41:283-284.

doi:10.1186/2046-7648-4-S1-A22

Cite this article as: House and de Sa: Comparison of performance on a heat tolerance test of military personnel that have suffered heat illness and subsequently been diagnosed with malignant hyperthermia and controls. Extreme Physiology \& Medicine 2015 4(Suppl 1):A22.

Submit your next manuscript to BioMed Central and take full advantage of:

- Convenient online submission

- Thorough peer review

- No space constraints or color figure charges

- Immediate publication on acceptance

- Inclusion in PubMed, CAS, Scopus and Google Scholar

- Research which is freely available for redistribution

Submit your manuscript at www.biomedcentral.com/submit 